\title{
WEAR RESISTANCE OF SPECIALIZED VEHICLES TIRES ON QUARRY ROADS
}

\section{VALERIY TOPALIDI ${ }^{1}$, UMIDBEK YUSUPOV $^{2 *}$ \& ALIJON BABAYEV ${ }^{3}$}

${ }^{1}$ Candidate of technical sciences, Professor of department Transport intelligent systems engineering, Tashkent state transport university, Tashkent, Uzbekistan

${ }^{2 *}$ PhD, Acting docent of department Vehicle engineering, Tashkent state transport university, Tashkent, Uzbekistan

${ }^{3}$ Candidate of technical sciences, Docent of department Construction and operation of armored vehicles, Military Technical Institute of the National Guard of the Republic of Uzbekistan, Tashkent, Uzbekistan

\section{ABSTRACT}

Vehicle tires are expensive products and have a relatively small resource. The operating costs of a tire for specialized vehicles operating in quarry conditions are up to $20 \%$ of the amount of transportation costs.

On the basis of experimental and theoretical studies of tire wear resistance of specialized vehicles, an original method of standardizing tire mileage, taking into account work in quarry conditions, has been developed. In the classification of operating conditions, an additional assessment of the road surface $D_{7}$ - intra-quarry and dump roads was introduced.

For the first time developed and introduced into scientific circulation coefficients for correcting the mileage of tires of specialized vehicles $K_{g p}$, depending on the category of rock strength on the scale of prof. M.M. Protodyakonov, on the basis of which career roads were laid. Linear correlation analysis of the $K_{g p}$ and $f$ coefficients showed that they have a strong negative correlation - according to Pearson's criterion -1, which confirms the correct choice of tire mileage correction coefficients depending on the breed category.

KEYWORDS: Tire Wear, Specialized Vehicles, Wear Resistance, Rationing, Quarry Roads, Rock Strength

Received: Sep 26, 2020; Accepted: Oct 16, 2020; Published: Nov 23, 2020; Paper Id.: IJMPERDOCT202064

\section{INTRODUCTION}

In the Republic of Uzbekistan, the extraction of valuable minerals has historically been one of the main components of the economy. More than 15 thousand vehicles operate in career conditions in Uzbekistan alone. Motor vehicle tires (VT) are expensive products and have a relatively small resource. The operating costs of a tire for specialized vehicles operating in quarry conditions are up to $20 \%$ of the amount of transportation costs. Until now, it remains an urgent problem to study the resource of tires of specialized vehicles in quarry conditions. Usually these are vehicles with a carrying capacity of 10 to 24 tons, used as a technological transport in small quarries, where the terrain does not allow the use of heavy-duty dump trucks. They also carry out important auxiliary work in large open pits: they deliver spare parts for mining equipment and technological transport, replacement equipment, special cargo, tankers and water carriers for irrigation, etc. [1, 2, 3].

Therefore, it was important to develop a universal method that would allow justifying the tire mileage of specialized vehicles by determining the correction coefficient for tire mileage taking into account the strength of 
the rock laid in the form of a road surface in quarries.

Scientific literature has numerous studies in the field of tire wear resistance and increasing their resource. Each of these studies differs in its approach to studying the problem and individual methods of solving it. However, all of them are aimed at improving the characteristics of tires, on the condition of which the vehicle's controllability, its driving performance, stability and comfort depend. In turn, the characteristics of tires are directly predetermined by the structural elements and physical and mechanical properties of the materials from which they are made, as well as by their operating conditions and working period [4].

O.B. Tretyakov, emphasizing the dependence of the tire service life on the type of road surface, pointed out that it is the highest $-100 \%$ on concrete and asphalt roads and significantly low $-25-40 \%$ when operating on such road surfaces, the surface of which has been improved. On the tire, its surface continues to be smooth on asphalt-concrete roads, the profile of which is flat. Meanwhile, on gravel roads, multiple cuts and scratches appear on the tire. According to the data [5, 6], on the road with $35 \%$ gravel surface, the tire tread wear increased by $30-70 \%$.

Various approaches are known for establishing tire life. For example, V.I. Savchugov builds his definition according to the fatigue life criterion on the basis of the following calculated dependence [7]:

$$
S=2 \cdot 10^{-6} \cdot \pi \cdot r_{k} \cdot c \cdot\left[\frac{2 \cdot E_{p}}{K_{0} \cdot U \cdot\left(\frac{\varepsilon_{c t} \cdot K_{\mathrm{M}}}{K_{t} \cdot K_{c}}\right)}\right]^{n_{w}}, \text { (1) }
$$

where $S$ is the tire resource, thousand $\mathrm{km} ; K_{d}$ - dynamic factor, taking into account the speed of movement and the condition of the road surface; $K_{0}$ - stress concentration factor; $E_{p}$ is the destruction energy of the sample under single loading, $\mathrm{MJ} / \mathrm{m}^{3} ; r_{\kappa}$ - wheel rolling radius, $\mathrm{m} ; c$ - the number of loading cycles per wheel revolution; $U$ - dynamic modulus of elasticity, MPa; $\varepsilon_{c t}$ is the maximum deformation of the most loaded elements of the tire under static loading,\%; $K_{t}$ coefficient taking into account temperature change; $K_{c}$ - coefficient of environmental influence.

R.M. Ustarov [8] established the operational factors affecting the wear and life of tires with varying terrain. The author, having created a model of mountain road conditions of interaction of the system "mountain road - car - driver environment", described a complex of factors. They covered driving techniques, road climatic conditions, vehicle structures; weight overload of tires; vehicle speed; tire pressure, etc. others. Along with this, the author conducted bench tests, emphasizing the appropriateness of using this technique for new routes. Moreover, they justified the need to enter the weighted average relief factor in the route passport and its further use when calculating tire mileage.

L.D. Slyudikov [9] theoretically substantiated and created a set of tools that contribute to increasing the resource of tires when designing their new models, consistent with technical requirements, features of production technology and conditions of their operation. Along with this, he has developed and introduced into production effective balanced solutions to ensure increased tire life. Having carried out systematic studies to determine the effect of tread parameters on durability, the author formulated ideas about the optimal combination of rubber properties and tread design, which ensures the maximum possible tire life.

Currently, scientific research on the durability and standardization of the mileage of tires of specialized vehicles, taking into account work in quarry conditions, is insufficiently conducted. This is due to the fact that the methods for correcting tire mileage related to the hardness of the rocks that form the basis of the open pit roads have not been 
determined.

The scientific significance of the research carried out is that for the first time a coefficient for correcting the mileage of vehicle tires in quarry conditions was introduced, taking into account the strength of the rocks on the basis of which the roads were built; revealed the dynamics of tire wear of specialized vehicles on various roads, taking into account career conditions $[3,4]$.

The practical significance of the results obtained lies in the fact that an original universal method is proposed for standardizing the mileage of vehicle tires for various categories of roads, taking into account career conditions; the developed methodology of resource rationing and the rules for operating tires of specialized vehicles on various categories of roads make it possible to plan costs and stocks of tires.

\section{EXPERIMENTAL RESEARCH}

Research on tire wear resistance was carried out in JSC "Almalyk Mining and Metallurgical Complex". AMMC is one of the largest metallurgical plants in Central Asia, with huge and small open pits for the extraction of non-ferrous metals. The specifics of the work of vehicles at all facilities of JSC "AMMC" is such that transportation routes can be divided into three sections:

- roads with improved coverage of the III category;

- roads with unpaved surface of IV category;

- $\quad$-pit roads built on the basis of hard rock.

An analysis of the roads at the Kalmakyr and Sary-Cheku quarries of the Almalyk Mining and Metallurgical Complex, where copper ore is mined, showed that all roads there are laid on the basis of hard rocks, which do not crumble into sand when crushed and rolled by bulldozers. Considering that in these quarries there is a lot of quartzite (up to 67\%), which is considered the hardest rock, all wheeled vehicles operating there will naturally experience intense tire wear $[3,4]$.

It was noted that even for bulldozers performing a huge amount of work on the roads of a quarry, the caterpillars wear out much earlier than planned.

Almost all roads inside the quarries (up to 90\%) are temporary technological and are designed for a service life of up to one year. Temporary roads are constantly "moving" following the front of excavation or dumping operations. These passages are arranged with bulldozers and motor graders directly on the ground without any coatings (Fig. 1) [4]. 


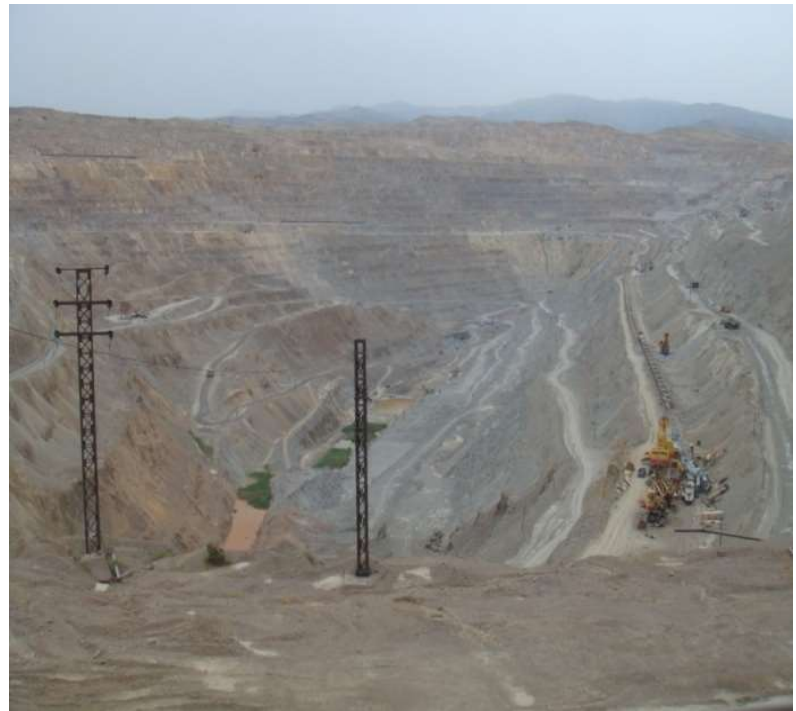

$\mathbf{a}$

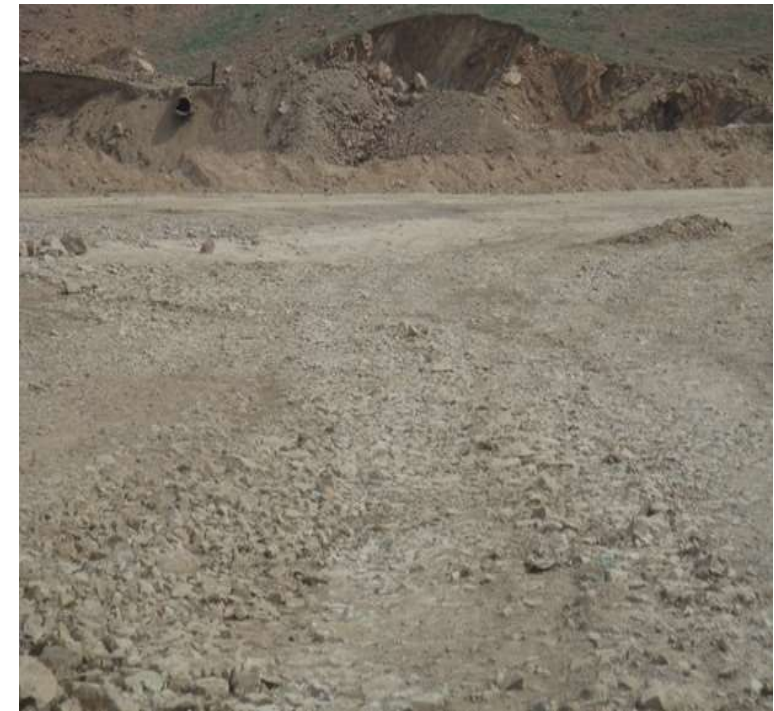

б

Figure 1: Open pit "Kalmakyr" (a) and roads of the open pit "Sary-Cheku" (b)

Specialized vehicles operating as a technological transport in the Angren and Chadak mining administrations (AMA and ChMA) of the AMMC are usually operated on three types of roads. Only in the ChMA there are 5 routes for the transportation of waste ore rock along the roads laid up to $97 \%$ on a solid rock foundation (Fig. 2).
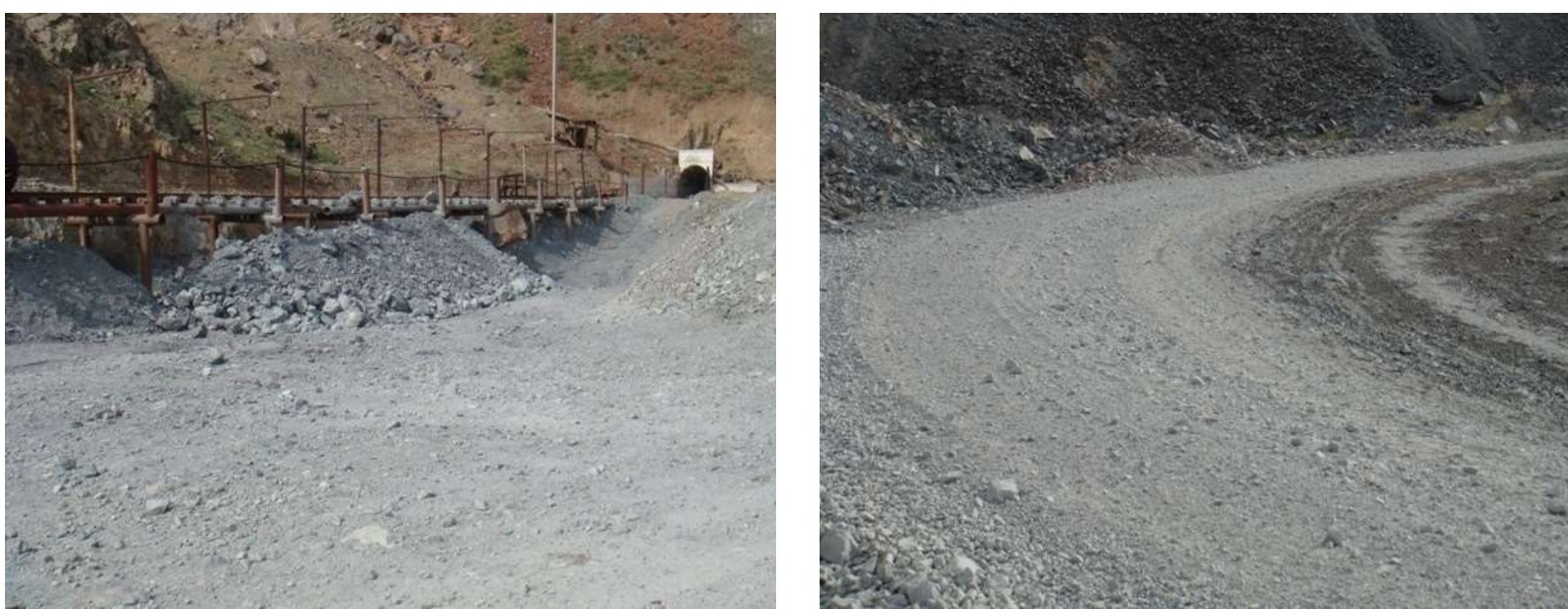

Figure 2: Road condition in Chadak MA

In the open-pit mines of the AMMC, the rock hardness coefficient f according to the M.M. Protodyakonov scale is 14-15 and belongs to the second category of rock - very strong.

The analysis of the condition of the decommissioned tires made it possible to draw certain conclusions regarding the reasons, mechanisms of wear and tear of tires during the operation of specialized vehicles at the Kalmakyr MA, AMA and ChMA.

The research was carried out strictly according to the developed plan (Fig. 3). 


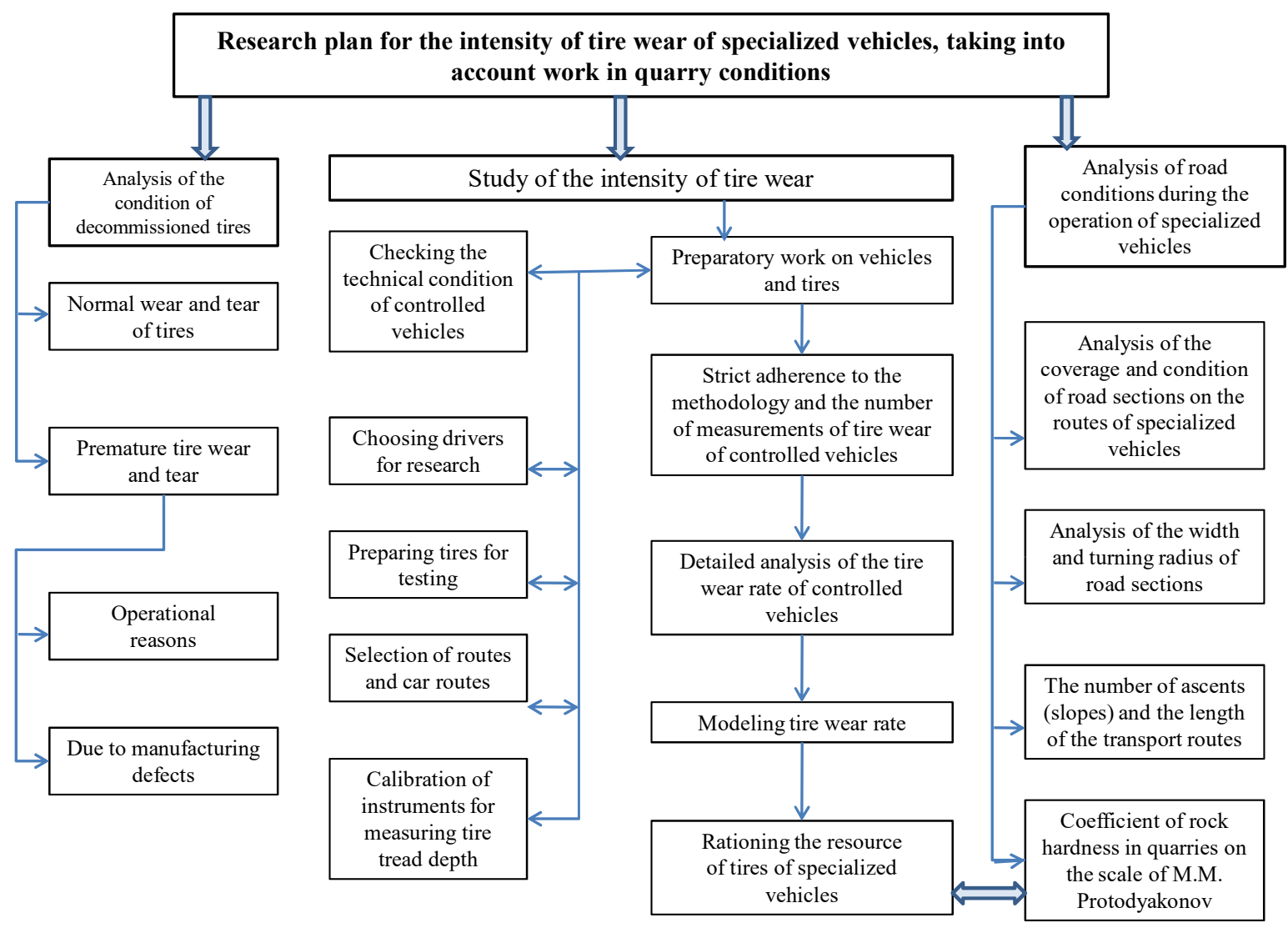

Figure 3: Tire wear rate study plan

Before the start of the research on the wear resistance of tires of specialized vehicles, preparatory work was carried out in accordance with the interstate GOST 28169 "Pneumatic tires. Methods for determining the wear resistance of tires during road tests ". Along with this, work was carried out on the technical condition of controlled vehicles, selection of qualified experienced drivers, calibration of devices for measuring tire tread depth and selection of routes for vehicles $[3,10]$.

In order to ensure the reliability of the assessment of experimental studies of tire wear, the number of measurements was justified so that the statistical error was no more than $5 \%$.

The calculations were carried out on the basis of the methodology specified in GOST 28169. In the calculations carried out, the formulas are substituted with real initial data obtained experimentally when studying the dynamics of tire wear in real open pit conditions of the ChMA.

For tires 315/80R22.5 model BEL-278, Belshina and model TR918 Triangle with a universal tread pattern, installed on MAN 33.360, the statistical error was

$$
P= \pm \sqrt{P_{1}^{2}+P_{2}^{2}}=\sqrt{2,94^{2}+3,28^{2}}=4,4 \%,(2)
$$

where $P_{1}$ is the statistical error in the sixth measurement of the Belshina tire; $P_{2}$ - statistical error in the sixth measurement of the Triangle tire. 

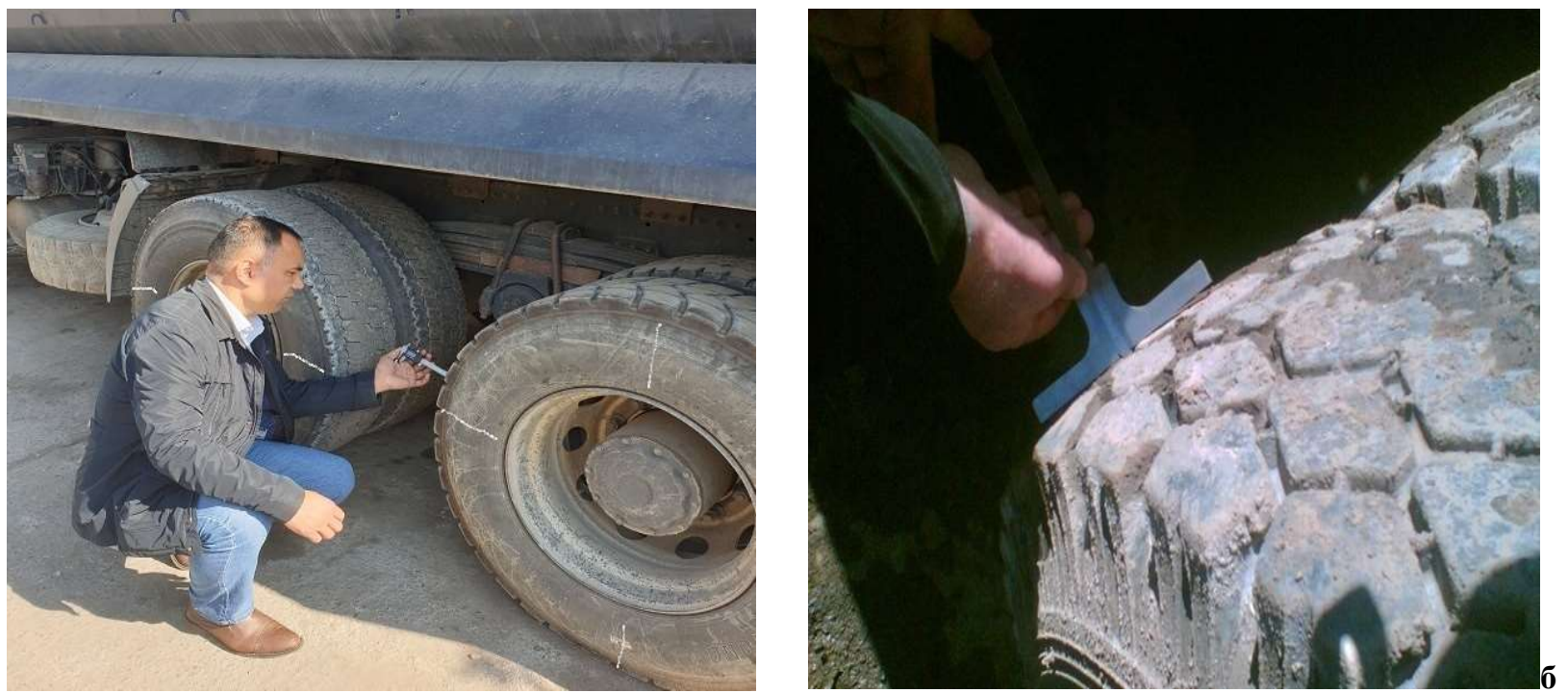

a

Figure 4: Measurement of tire tread height with electronic (a) and mechanical depth gauge "BRIDGESTONE" (b)

Tire wear measurements were carried out within 4-6 months at intervals of 2-6 thousand km. In total, about 220 cars and more than 1400 tires were involved in the experiments to determine the intensity of tire wear. For all experimental studies of tire wear resistance, at least 6 measurements were carried out (Fig. 4) [1 - 4].

In the Kalmakyr MA, specialized auxiliary transport is operated on various road sections: roads with an improved surface of the III category, roads with an unpaved surface of the IV category and quarry roads laid on the basis of hard rocks. Moreover, different groups of such vehicles have different lengths of each road section.

It should be noted that $43.3 \%$ of the routes for the transportation of MAN 33.360, ISUZU 51KLD and KrAZ65055 dump trucks in the Angren MA is a gold recovery plant - mines and adits are laid on roads with a natural rocky base. Transportation routes for road transport are constantly changing, therefore, the results of tracking tire wear resistance characterize the whole picture throughout the AMA. Figure 5 shows the characteristics of tire wear of one of the KrAZ65055 dump trucks (in total, there were 4 lots of 5 dump trucks in the AMA during testing). 

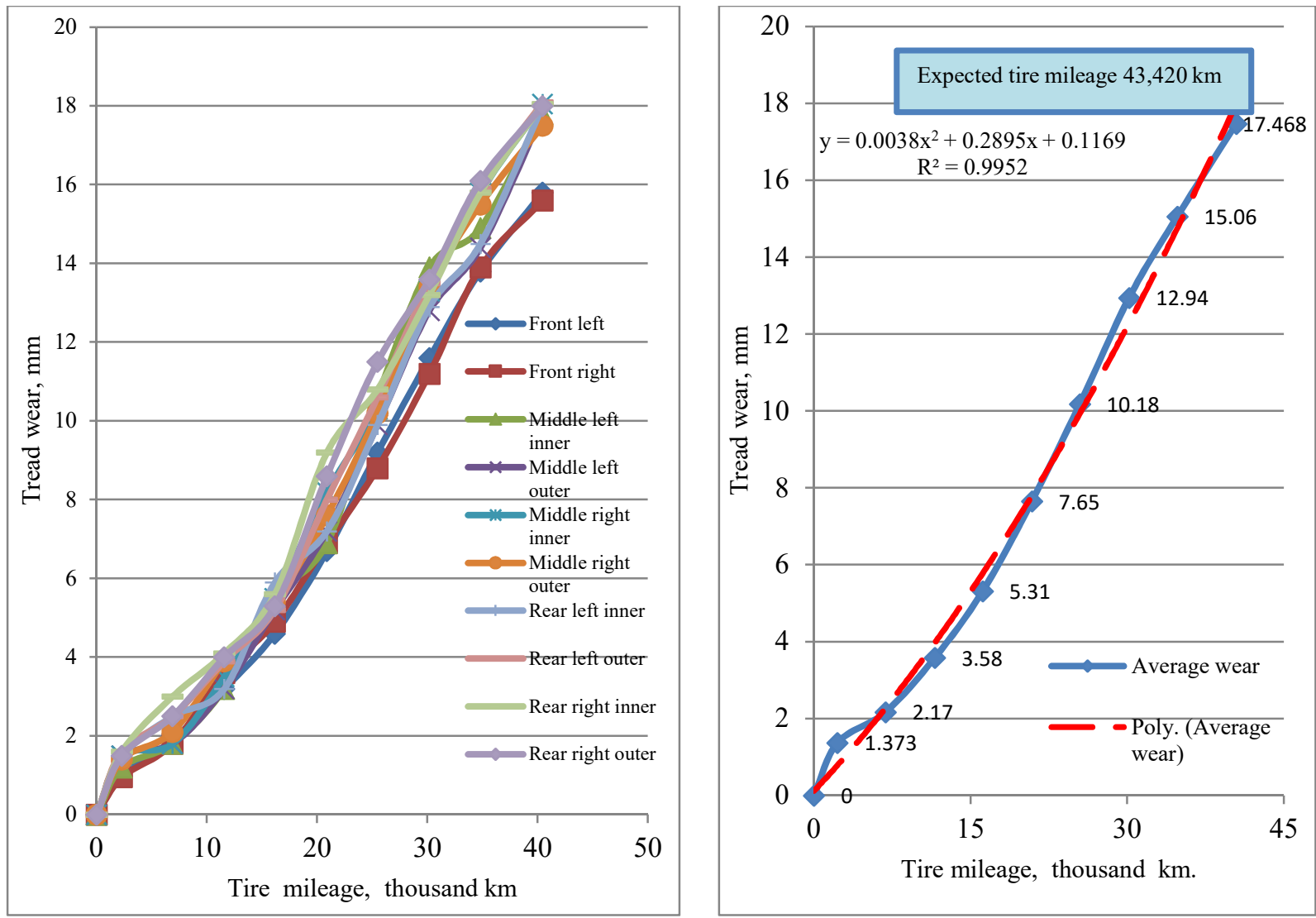

Figure 5: Tread wear characteristics for the KrAZ-65055 dump truck, No. 10.140XAA, tire size 12.00R20 TRIANGLE. Angren MA.

The final results of experimental studies carried out at one of the AMMC open pits in the Chadak MA were taken as the basis for standardizing the running of tires of specialized vehicles on open pit roads laid on the basis of hard rocks.

Due to the terrain, three-axle dump trucks MAN TGS 33.360 and KrAZ-65055 are used as a technological transport of the ChMA. The dump trucks are equipped with 315/80R22.5 tires manufactured by Belshina, model BEL-278 and 12.00R20, model TTO-A112 TRIANGLE with a universal tread pattern. In calculating the standard tire mileage, two well-known methods were used - graphical analytical and mathematical statistics.

Coefficients of rock hardness $f=14-15$ according to M.M. Protodyakonov's scale. Figure 5 shows the tire wear characteristics of the MAN 33.360 dump truck, tire size 315 / 80R22.5, manufacturer Belshina, model BEL-278 (Figure 6).

The roads in the ChMA are very narrow, the routes are short, the distances are from 0.6 to $5.1 \mathrm{~km}$, there are 26 routes in total. In AMA and ChMA, all movements of dump trucks were recorded on separate cards, and changes in the tire tread height, i.e. tire wear was recorded in a special record card [3]. 

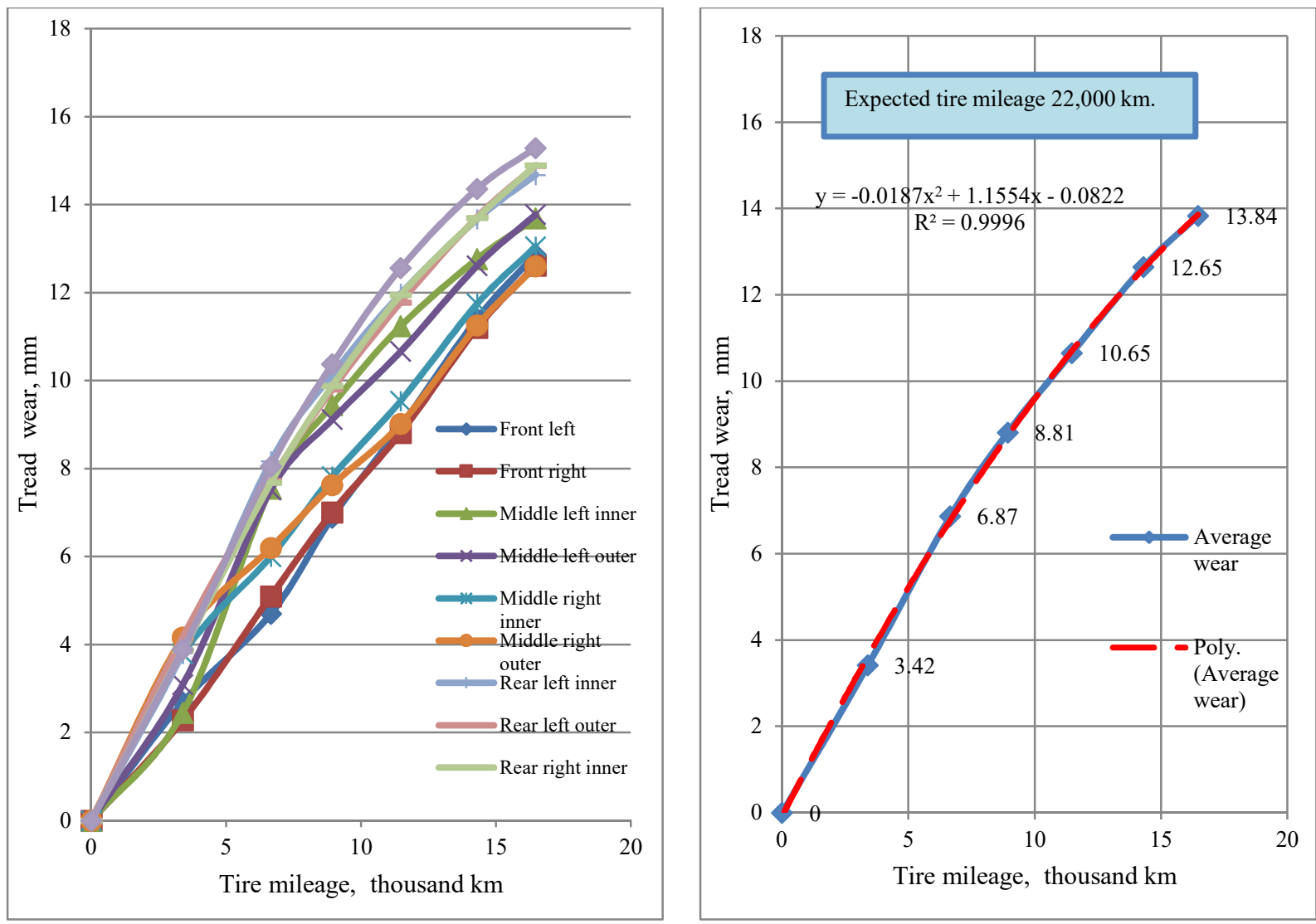

Figure 6: Characteristics of the tread wear of each tire and the average tire wear of the MAN 33.360 dump truck, No. 10.702 NAA, tire size 315/80R22.5, manufacturer Belshina,

\section{Chadak MA.}

\section{MAIN PART}

Taking into account the impact of road surface on tire wear, especially in quarry conditions based on hard rock, it is proposed in the classification of operating conditions [11] to cover $D_{6}$ roads - natural unpaved roads, unpaved access roads, temporary in-quarry and dump roads to be divided into 2 categories:

$D_{6}$ - natural unpaved roads, access roads without hard surface;

$D_{7}$ - temporary intra-quarry and dump roads (Table 1$)$.

\section{CLASSIFICATION OF USE CONDITIONS}

Table 1

\begin{tabular}{|l|l|l|l|l|}
\hline $\begin{array}{c}\text { Category } \\
\text { conditions } \\
\text { exploitation }\end{array}$ & $\begin{array}{c}\text { Outside commuter } \\
\text { Zones (more than 50 } \\
\mathbf{k m} \text { from the border } \\
\text { cities) }\end{array}$ & $\begin{array}{c}\text { In small towns (up to } \\
\mathbf{1 0 0} \text { thousand } \\
\text { inhabitants) and in the } \\
\text { suburban area }\end{array}$ & $\begin{array}{c}\text { In big cities } \\
\text { (more than } \mathbf{1 0 0} \\
\text { thousand. } \\
\text { residents) }\end{array}$ & $\begin{array}{c}\text { National economic and } \\
\text { administrative } \\
\text { significance of the } \\
\text { highway }\end{array}$ \\
\hline $\mathrm{I}$ & $\mathrm{D}_{1}-\mathrm{P}_{1}, \mathrm{P}_{2}, \mathrm{P}_{3}$ & - & $\begin{array}{l}\text { Ia - main roads of national } \\
\text { importance, including for } \\
\text { international traffic }\end{array}$ \\
\hline
\end{tabular}




\begin{tabular}{|c|c|c|c|c|}
\hline & & & & $\begin{array}{l}\text { Ib - highways of national } \\
\text { (not classified as Ia), } \\
\text { republican, regional } \\
\text { (regional) significance }\end{array}$ \\
\hline II & $\begin{array}{l}\mathrm{D}_{1}-\mathrm{P}_{4} \\
\mathrm{D}_{2}-\mathrm{P}_{1}, \mathrm{P}_{2}, \mathrm{P}_{3}, \mathrm{P}_{4} \\
\mathrm{D}_{3}-\mathrm{P}_{1}, \mathrm{P}_{2}, \mathrm{P}_{3}\end{array}$ & $\begin{array}{l}\mathrm{D}_{1}-\mathrm{P}_{1}, \mathrm{P}_{2}, \mathrm{P}_{3}, \mathrm{P}_{4} \\
\mathrm{D}_{2}-\mathrm{P}_{1}\end{array}$ & - & $\begin{array}{l}\text { Highways of national (not } \\
\text { classified as Ia, I6), } \\
\text { republican, regional } \\
\text { (regional) significance }\end{array}$ \\
\hline III & $\begin{array}{l}\mathrm{D}_{1}-\mathrm{P}_{5} \\
\mathrm{D}_{2}-\mathrm{P}_{5} \\
\mathrm{D}_{3}-\mathrm{P}_{4}, \mathrm{P}_{5} \\
\mathrm{D}_{4}-\mathrm{P}_{1}, \mathrm{P}_{2}, \mathrm{P}_{3}, \mathrm{P}_{4}, \mathrm{P}_{5}\end{array}$ & $\begin{array}{l}\mathrm{D}_{1}-\mathrm{P}_{5} \\
\mathrm{D}_{2}-\mathrm{P}_{2}, \mathrm{P}_{3}, \mathrm{P}_{4}, \mathrm{P}_{5} \\
\mathrm{D}_{3}-\mathrm{P}_{1}, \mathrm{P}_{2}, \mathrm{P}_{3}, \mathrm{P}_{4}, \mathrm{P}_{5} \\
\mathrm{D}_{4}-\mathrm{P}_{1}, \mathrm{P}_{2}, \mathrm{P}_{3}, \mathrm{P}_{4}, \mathrm{P}_{5}\end{array}$ & $\begin{array}{l}\mathrm{D}_{1}-\mathrm{P}_{1}, \mathrm{P}_{2}, \mathrm{P}_{3}, \mathrm{P}_{4}, \mathrm{P}_{5} \\
\mathrm{D}_{2}-\mathrm{P}_{1}, \mathrm{P}_{2}, \mathrm{P}_{3}, \mathrm{P}_{4} \\
\mathrm{D}_{3}-\mathrm{P}_{1}, \mathrm{P}_{2}, \mathrm{P}_{3} \\
\mathrm{D}_{4}-\mathrm{P}_{1}\end{array}$ & $\begin{array}{l}\text { Highways of the state, } \\
\text { republican (regional) (not } \\
\text { classified into category Ia } \\
\text { and II), local roads }\end{array}$ \\
\hline IV & $\mathrm{D}_{5}-\mathrm{P}_{1}, \mathrm{P}_{2}, \mathrm{P}_{3}, \mathrm{P}_{4}, \mathrm{P}_{5}$ & $\mathrm{D}_{5}-\mathrm{P}_{1}, \mathrm{P}_{2}, \mathrm{P}_{3}, \mathrm{P}_{4}, \mathrm{P}_{5}$ & $\begin{array}{l}\mathrm{D}_{2}-\mathrm{P}_{5} \\
\mathrm{D}_{3}-\mathrm{P}_{4}, \mathrm{P}_{5} \\
\mathrm{D}_{4}-\mathrm{P}_{1}, \mathrm{P}_{2}, \mathrm{P}_{3}, \mathrm{P}_{4}, \mathrm{P}_{5} \\
\mathrm{D}_{5}-\mathrm{P}_{1}, \mathrm{P}_{2}, \mathrm{P}_{3}, \mathrm{P}_{4}, \mathrm{P}_{5}\end{array}$ & $\begin{array}{l}\text { Highways of republican } \\
\text { oblast (regional) and local } \\
\text { significance (not assigned } \\
\text { to categories Ib, II, III) }\end{array}$ \\
\hline $\mathrm{V}_{\mathrm{a}}$ & \multicolumn{3}{|c|}{$\begin{array}{l}\mathrm{D}_{6}-\mathrm{P}_{1}, \mathrm{P}_{2} \mathrm{D}_{7}-\mathrm{P}_{1}, \mathrm{P}_{2} \\
\mathrm{D}_{6}-\mathrm{P}_{3}, \mathrm{P}_{4}, \mathrm{P}_{5} \mathrm{D}_{7}-\mathrm{P}_{3}, \mathrm{P}_{4}, \mathrm{P}_{5}\end{array}$} & $\begin{array}{l}\text { Highways of local } \\
\text { importance and quarry } \\
\text { roads (except for those } \\
\text { assigned to categories III, } \\
\text { IV) }\end{array}$ \\
\hline
\end{tabular}

\section{Road Surfaces}

$\mathrm{D}_{1}$ - cement concrete, asphalt concrete, paving stones, mosaic; $\mathrm{D}_{2}$ - bitumen-mineral mixtures (crushed stone or gravel treated with bitumen); $\mathrm{D}_{3}$ - crushed stone (gravel) without processing, tar concrete; $\mathrm{D}_{4}$ - cobblestone, crushed stone, soil and low-strength stone treated with binders, winter roads; $\mathrm{D}_{5}$ - soil reinforced or improved with local materials; plank and $\log$ coverings; $\mathrm{D}_{6}$ - natural dirt roads; driveways that are not paved; $\mathrm{D}_{7}$ - temporary intra-quarry and dump roads.

\section{Terrain type (determined by the height above sea level):}

$\mathrm{P}_{1}$ - flat (up to $200 \mathrm{~m}$ ); $\mathrm{P}_{2}$ - slightly hilly (over $200 \mathrm{~m}$ to $300 \mathrm{~m}$ ); $\mathrm{P}_{3}$ - hilly (over $300 \mathrm{~m}$ to $1000 \mathrm{~m}$ ); $\mathrm{P}_{4}$ - mountainous (over $1000 \mathrm{~m}$ to $2000 \mathrm{~m}$ ); $\mathrm{P}_{5}$ - mountain (over $2000 \mathrm{~m}$ ).

In addition, taking into account what effect the height and terrain has on tire wear when working in deep quarries, the V-category of operating conditions was divided into two subcategories [4]:

$$
\begin{aligned}
& \mathrm{V}_{\mathrm{a}}-\mathrm{D}_{6}-\mathrm{P}_{1}, \mathrm{P}_{2} ; \mathrm{D}_{7}-\mathrm{P}_{1}, \mathrm{P}_{2} \\
& \mathrm{~V}_{\mathrm{b}}-\mathrm{D}_{6}-\mathrm{P}_{3}, \mathrm{P}_{4}, \mathrm{P}_{5} ; \mathrm{D}_{7}-\mathrm{P}_{3}, \mathrm{P}_{4}, \mathrm{P}_{5} .
\end{aligned}
$$

These proposals allow for a more accurate calculation of tire wear rates.

Research carried out in the ChMA showed that the coefficient of correction of tire mileage, if dump trucks operate only on roads with rocky soil, we determine $K_{g p}[5]$ :

$$
K_{g p}=\frac{L}{S_{n}}=\frac{22000}{80000}=0,275
$$

Here, $L$ is the actual tire mileage of 10 dump trucks (100 tires) of the study; $S_{n}$ - standard tire mileage established for I-category roads (Belshina, model BEL-278, tire size 315/80R22.5).

Similar studies on tire wear on the same MAN 33.360 dump truck were carried out at Uzbekkumir JSC and Kizilkumcement JSC, where $f=1.0$ and $f=6.0$, respectively, tire mileage correction factors $K_{g p}=0.8$ and $K_{g p}=0.61$. Thus, 
the following pairs of dependences of rock hardness coefficients $\mathrm{f}$ and correction of tire mileage $K_{g p}$ have been established $[1,2,3]:$

\begin{tabular}{|c|c|c|c|}
\hline Coefficients & JSC "AMMC" & Kizilkumcement JSC & Uzbekkumir JSC \\
\hline$f$ & 15 & 6 & 1 \\
\hline$K_{g p}$ & 0,275 & 0,61 & 0,8 \\
\hline
\end{tabular}

An interpolation polynomial passing through these points is constructed. Calculations have shown that the linear dependence uniquely describes the line passing through these points:

$$
y=-0,0375 x+0,8375
$$

In order to predict tire mileage correction coefficients for other breeds, extrapolation was carried out for all categories of breeds and the values of $K_{g p}$ were determined.

Table 2: Extrapolation for all categories of rocks on the scale of M.M. Protodyakonov [13]

\begin{tabular}{|c|c|c|c|c|c|}
\hline № & $\begin{array}{c}\text { Breed } \\
\text { category }\end{array}$ & $\begin{array}{c}\text { Fortress } \\
\text { degree }\end{array}$ & $\begin{array}{c}\text { Breeds } \\
\text { (scale of Prof. M.M. Protodyakonov) }\end{array}$ & $\begin{array}{c}\text { Fortress } \\
\text { coefficient } \\
f\end{array}$ & $\begin{array}{c}\text { Correction } \\
\text { factor } \\
\text { tire mileage } \\
K_{g p}\end{array}$ \\
\hline 1 & 2 & 3 & 4 & 5 & 6 \\
\hline 1. & I & $\begin{array}{l}\text { Extremely } \\
\text { strong }\end{array}$ & $\begin{array}{l}\text { The strongest, densest and most viscous } \\
\text { quartzites and basalts. Other breeds of } \\
\text { exceptional strength. }\end{array}$ & 20 & 0,0875 \\
\hline 2. & II & $\begin{array}{l}\text { Very } \\
\text { strong }\end{array}$ & $\begin{array}{l}\text { Very hard granite rocks. Quartz porphyry, very } \\
\text { hard granite, siliceous shale. Less strong than the } \\
\text { above quartzites. The hardest sandstones and } \\
\text { limestones. }\end{array}$ & 15 & 0,275 \\
\hline 3. & III & Strong & $\begin{array}{l}\text { Granite (dense) and granite rocks. Very hard } \\
\text { sandstones and limestones. Quartz ore veins. } \\
\text { Strong conglomerate. Very hard iron ore. }\end{array}$ & 10 & 0,4625 \\
\hline 4. & III a & Strong & $\begin{array}{l}\text { Limestone (hard). Weak granite. Strong } \\
\text { sandstones. Strong marble. Dolomite. Pyrite. }\end{array}$ & 8 & 0,5375 \\
\hline 5. & IV & $\begin{array}{l}\text { Pretty } \\
\text { strong }\end{array}$ & Ordinary sandstone. Iron ores. & 6 & 0,6125 \\
\hline 6. & IV a & $\begin{array}{l}\text { Pretty } \\
\text { strong }\end{array}$ & Sandy shales. Shale sandstones. & 5 & 0,65 \\
\hline 7. & $\mathrm{~V}$ & $\begin{array}{l}\text { Medium } \\
\text { fortress }\end{array}$ & $\begin{array}{l}\text { Strong shale. Weak sandstone and limestone, soft } \\
\text { conglomerate. }\end{array}$ & 4 & 0,6875 \\
\hline 8. & $\mathrm{~V}$ a & $\begin{array}{l}\text { Medium } \\
\text { fortress }\end{array}$ & Various shales (weak). Dense marl. & 3 & 0,725 \\
\hline 9 & VI & Quite soft & $\begin{array}{l}\text { Soft shale, very soft limestone, chalk, rock salt, } \\
\text { gypsum. Frozen ground, anthracite. Ordinary } \\
\text { marl. Destroyed sandstone, cemented pebbles, } \\
\text { rocky ground. }\end{array}$ & 2 & 0,7625 \\
\hline 10 & VI a & Quite soft & $\begin{array}{l}\text { Crushed rock. Destroyed shale, compacted } \\
\text { pebbles and rubble. Strong coal. Opened clay. }\end{array}$ & 1,5 & 0,78125 \\
\hline 11 & VII & Soft & $\begin{array}{l}\text { Clay (dense). Soft coal. Strong sediment, clayey } \\
\text { soil. }\end{array}$ & 1 & 0,8 \\
\hline 12 & VII a & Soft & Light sandy clay, loess, gravel. & 0,8 & 0,8075 \\
\hline 13 & VIII & Earthy & Vegetable land. Peat. Light loam, damp sand. & 0,6 & 0,815 \\
\hline 14 & IX & Loose & Sand, talus, fine gravel, bulk earth, mined coal. & 0,5 & 0,81875 \\
\hline 15 & $\mathrm{X}$ & Floating & Quicksands, swampy ground, thinned loess, etc. & 0,3 & 0,82625 \\
\hline
\end{tabular}


Let's carry out a correlation analysis of the values of the coefficients $f$ and Kgp using the linear Pearson correlation.

In general terms, the formula for calculating the correlation coefficient is as follows:

$$
r_{x y}=\frac{\sum\left(x_{i}-\bar{x}\right) \cdot\left(y_{i}-\bar{y}\right)}{\sqrt{\sum\left(x_{i}-\bar{x}\right)^{2} \cdot\left(y_{i}-\bar{y}\right)^{2}}}
$$

where $\mathrm{x}_{\mathrm{i}}$ - values taken by the variable $\mathrm{X} ; \mathrm{y}_{\mathrm{i}}$ - values taken by the variable $\mathrm{Y} ; \bar{x}$ - average for $\mathrm{X} ; \bar{y}$ - average on $\mathrm{Y}[12]$

From formula (5), it is clear that it is necessary to subtract the average value $\mathrm{x}$ variable from each value $x_{i}$ of the variable $\mathrm{X}$, which is very difficult. Based on this, calculations to determine the correlation coefficient are made according to a similar formula, compiled using transformations:

$$
P_{x y}=\frac{n * \sum\left(x_{i} * y_{i}\right)-\left(\sum x_{i} * \sum y_{i}\right)}{\sqrt{\left[n * \sum x_{i}^{2}-\left(\sum x_{i}\right)^{2}\right] *\left[n * \sum y_{i}^{2}-\left(\sum y_{i}\right)^{2}\right]}} .
$$

Using this formula, we will solve the problem. The main basis for this will be the data in Table 3 , in particular from the calculation graphs by the formula. Specific values and squares of the variables $\mathrm{X}$ and $\mathrm{Y}$, their line products and sums are presented in table 3 .

Table 3: Individual values of variables $X$ and $Y$

\begin{tabular}{|c|c|c|c|c|c|}
\hline \multirow{2}{*}{$\begin{array}{c}\text { Breed } \\
\text { category }\end{array}$} & $\begin{array}{c}\boldsymbol{X} \\
\text { fortress coefficient, } \\
\boldsymbol{f}\end{array}$ & $\begin{array}{c}\boldsymbol{Y} \\
\text { tire mileage correction } \\
\text { factor, } \boldsymbol{K}_{\boldsymbol{n} \text { n }}\end{array}$ & $\boldsymbol{X} \cdot \boldsymbol{Y}$ & $\boldsymbol{X} \cdot \boldsymbol{X}$ & $\boldsymbol{Y} \cdot \boldsymbol{Y}$ \\
\hline 1 & 20 & 0,0875 & 1,75 & 400 & 0,007656 \\
\hline 2 & 15 & 0,275 & 4,125 & 225 & 0,075625 \\
\hline 3 & 10 & 0,4625 & 4,625 & 100 & 0,213906 \\
\hline 4 & 8 & 0,5375 & 4,3 & 64 & 0,288906 \\
\hline 5 & 6 & 0,6125 & 3,675 & 36 & 0,375156 \\
\hline 6 & 5 & 0,65 & 3,25 & 25 & 0,4225 \\
\hline 7 & 4 & 0,6875 & 2,75 & 16 & 0,472656 \\
\hline 8 & 3 & 0,725 & 2,175 & 9 & 0,525625 \\
\hline 9 & 2 & 0,7625 & 1,525 & 4 & 0,581406 \\
\hline 10 & 1,5 & 0,78125 & 1,171875 & 2,25 & 0,610352 \\
\hline 11 & 1 & 0,8 & 0,8 & 1 & 0,64 \\
\hline 12 & 0,8 & 0,8075 & 0,646 & 0,64 & 0,652056 \\
\hline 13 & 0,6 & 0,815 & 0,489 & 0,36 & 0,664225 \\
\hline 14 & 0,5 & 0,81875 & 0,409375 & 0,25 & 0,670352 \\
\hline 15 & 0,3 & 0,82625 & 0,247875 & 0,09 & 0,682689 \\
\hline total & 77,7 & 9,64875 & 31,93913 & 883,59 & 6,883111 \\
\hline
\end{tabular}

We calculate the empirical value of the correlation coefficient using the formula

$P_{x y}=\frac{15 * 31,93913-77,7 * 9,64875}{\sqrt{(15 * 883,59-7,7 * 77,7) *(15 * 6,883111-9,64875 * 9,64875)}}=-1$

The Pearson correlation coefficient for the $\mathrm{f}$ and $K_{g p}$ values was -1, i.e. the rock hardness and tire mileage correction factors have a strong negative correlation, which confirms the correct choice of tire mileage correction factors depending on the breed category. 
For clarity, Fig. 7 shows the dependences of the change in the coefficients $f$ and $K_{g p}$.

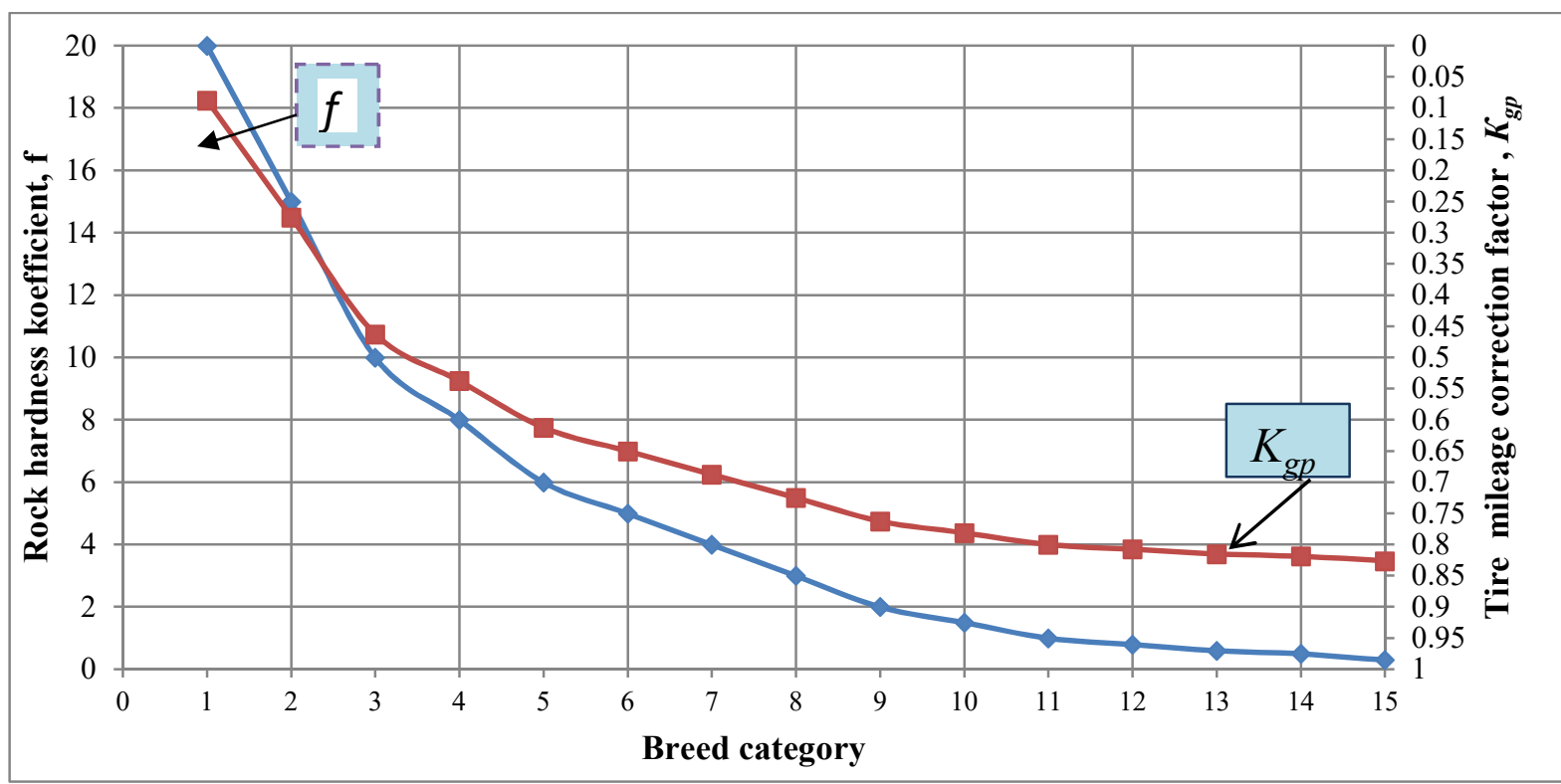

Figure 7: Characteristics of the dependence of the coefficients $f$ and $K_{g p}$ on the breed category

The presence of the $K_{g p}$ coefficient for all categories of breeds made it possible to propose an original method of standardizing the mileage of tires for vehicles with a carrying capacity of 10 to 24 tons.

The universal original method of standardizing the mileage of tires of specialized vehicles, taking into account work in quarry conditions, is the following formula [4]:

$S=S_{n}\left[L_{1} * K_{1}+L_{2} * K_{2}+L_{3} * K_{3}+L_{4} * K_{4}+L_{5 a} * K_{a г \Pi}+L_{5 b} * K_{b г \Pi}\right](8)$

where $S_{n}$ is the standard tire mileage established for category I roads;

$L_{1}, L_{2}, L_{3}, L_{4}$ - percentage of the length of the road for certain categories;

$L_{5 a}, L_{5 b}$ - the percentage of the length of open pit roads, taking into account the depth of the open pit;

$K_{1} \ldots K_{4}$ - correction factors for tires of cars operating in I, II, III, IV-th categories of operating conditions (CCE);

$K_{a g p}, K_{b g p}$ - coefficient of tire mileage correction, taking into account the strength of rocks [1, 2, 3].

This technique allows you to set the mileage rate of specialized vehicles with a carrying capacity of 10 to 24 tons, taking into account the work on any roads.

\section{ECONOMIC EFFECT}

The economic effect from the implementation of the developed method for standardizing the resource of tires consists of the following three components:

- The developed original method of tire rationing eliminates the need for high-cost, complex, long-term experimental studies of tire mileage in open pits with different rock hardness.

- 2. The new method of rationing tire mileage provides the right to choose a model and manufacturer of tires for specialized vehicles in order to more efficiently operate them on the career roads of specific enterprises. 
- 3. The proposed method of rationing the resource of tires allows enterprises to accurately plan the consumption and stock of tires of vehicles, partially operated in quarry conditions with different hardness of rocks, on the basis of which quarry roads are laid.

We also note that the method used in the dissertation for predicting tire mileage correction coefficients can be used for a wide range of other standard sizes of vehicle tires on roads laid in quarries with different hardness of the rocks from which they are made.

Let's consider an example of choosing tires for ChMA. Analysis of the production and operating experience of tires manufactured in China, in general, showed that the highest quality tires for MAN 33.360 and KrAZ-65055 dump trucks are manufactured by Triangle.

Department of automobile transport AMMC proposes to purchase 12.00R20 tires for KrAZ-65055 dump trucks of TTOA112, TR915, TR919, TR691-JS, TR691E (Triangle) dump trucks with a universal tire pattern, and for MAN 33.360 dump trucks - tires of 315/80R22.5 model TR918 ( Triangle).

Calculations according to the proposed method show that with a norm of $80,000 \mathrm{~km}$ of these tires on asphalt roads, on the roads of the ChMA, the mileage will be $36,000 \mathrm{~km}$.

The expected annual economic efficiency from the installation of 10 12.00R20 tires, models TTO-A112, TR915, TR919, TR691-JS, TR691E with an 18-20-layer Triangle tire, on the KrAZ-65055 dump truck operating at ChMA facilities, will amount to 6510000 soums. The calculation was carried out based on the operating conditions of dump trucks, which have an annual mileage of about $36,000 \mathrm{~km}$. At the moment, according to temporary norms, tires are written off after 30,000 km. Therefore, it is necessary to purchase 10 tires for one KrAZ 65055 dump truck per year. If the tires of the TTO-A112, TR915, TR919, TR691-JS, TR691E "Triangle" models are used on the KrAZ-65055 dump truck, with a mileage of 36,000 km before write-off, then 10 tires will be required per year. Annual savings for 1 dump truck will be 2 tires. The average price of this tire in Uzbekistan is about 3,255,000 soums.

The expected annual economic effect for one dump truck is determined by the formula:

$E=\frac{S\left[L_{f p}-L_{\mathrm{HI}}\right] \cdot K_{n t}}{L_{\mathrm{HI}}}=\frac{3255000[36000-30000] \cdot 10}{30000}=6510000$ soums $(9)$

Where, $S$ is the price of a tire, sum; $L_{f p}$ - actual tire mileage, $\mathrm{km} ; L_{n n}$ - tire run rate, $\mathrm{km} ; K_{n t}$ - the number of tires, units.

At the moment, the DAT JSC "AMMC" includes 8 motor depots, 1 tractor fleet and more than 1400 vehicles. In 2019, the 2nd, 3rd and 6th motor depots used 2,840 tires for specialized vehicles worth more than 9.2 billion soums.

If we take into account that about 220 such vehicles are operated in the AMA, ChMA and Kalmakyr MA, then using the proposed tire models the total annual economic effect will be over 1.4 billion soums.

\section{CONCLUSIONS}

Based on the studies performed, the following conclusions can be formulated:

- Quarry roads, as a rule, do not have an improved surface, as they are built on the basis of the rock of a particular quarry. The roads in the open pits of JSC "AMMA" are laid on the basis of hard rocks, which, when crushed and 
rolled by bulldozers, do not crumble into sand. Considering that in these quarries there is a lot of quartzite (up to $67 \%$ ), which is considered the hardest rock, all wheeled vehicles operating there are subject to intense tire wear.

- For the first time developed and introduced into scientific circulation coefficients for correcting the mileage of tires of specialized vehicles $K_{g p}$, depending on the category of rock strength on the scale of prof. M.M. Protodyakonov, on the basis of which career roads were laid. Linear correlation analysis of the $K_{g p}$ and $\mathrm{f}$ coefficients showed that they have a strong negative correlation - according to Pearson's criterion -1, which confirms the correct choice of tire mileage correction coefficients depending on the breed category.

- Detailed experimental studies of tire wear resistance were carried out on 220 cars and more than 1400 tires. The characteristic features of tire wear of specialized vehicles operating at all three facilities of the AMA, ChMA, Kalmakyr MA, on sections of roads partially with improved and unpaved surfaces, as well as on open pit roads have been identified. In the ChMA alone, there are 26 routes for dump trucks, 5 of them, laid on hard rocks, make up $95-97 \%$ of the total length of these routes.

- For the reliability of the results of the experiment with an error of up to $5 \%$ on each car, the tire tread wear was measured at least 6 times with an interval of 2-6 thousand $\mathrm{km}$. The coefficient of decreasing the resource of tires of specialized vehicles during operation on quarry roads laid on rocky ground was $K_{g p}=0.275$. In this case, the coefficient of rock hardness according to M.M. Protodyakonov was $f=15$.

- The coefficients for correcting the mileage of tires of specialized vehicles have been developed and introduced, depending on the category of rock fortress, on the basis of which the quarry roads were laid. As a result, the availability of tire mileage correction coefficients, depending on the hardness of the rocks of the opencast roads, ensure the rationing of the tire mileage of specialized vehicles used in any quarries.

- An original universal method of standardizing the mileage of tires of vehicles on various roads is proposed, taking into account work in a career. This methodology and all the latest recommendations for the selection and correction of tire mileage were included in the "Handbook on the rules of operation and standardization of the resource of tires of vehicles in the AMMC", transferred to JSC "AMMC" for implementation.

The approximate annual economic effect from the introduction of recommendations on the methods of standardizing the resource of tires, the choice of tires and the rules for their operation for vehicles in JSC "Almalyk MMC" on the example of one KrAZ-65055 dump truck with a tire size of 12.00R20, amounted to 6510000 soums.

\section{REFERENCES}

1. TARI report under contract No. 2007 dated March 1, 2015. on the topic: "Determination of the actual mileage of tires of vehicles operated in JSC" Uzbekkumir "'".

2. TIDCMAR report under contract No. 132/2016 dated April 13, 2016. on the topic: Determination of scientifically grounded norms of mileage of tires of motor vehicles operated in the conditions of JSC "Kizilkumcement".

3. Report of the TSC "BILIMINTERTRANS" under the contract 02/06 with JSC AMMC "Research and standardization of the service life of tires for industrial vehicles KrAZ-65055 and MAN 33.360 a / b No. 2 in the open pit conditions of AMA" 2018. Part I, II, III. 
4. Topalidi V.A., Yusupov U.B. Rationing the resource of truck tires in career conditions // Automotive Industry. -2019. -№11. S. 27 - 29.

5. Tarnovsky V.N., Gudkov V.L., Tretyakov O.B., Automobile tires. M.: Transport 1990.-272 p.

6. Tretyakov O.B. Friction and wear of tires / Tretyakov O.B., Tarnovsky V.N., Gudkov V.A. - M .: Chemistry, 1992 .-- 176 p.

7. Savchugov V.I. Correction of resource standards for tires of special vehicles: Dis ... cand. tech. sciences. - Tyumen, 2005 .-$174 p$.

8. Ustarov R.M. Prediction of the mileage of automobile tires operated in conditions of variable terrain: Dis ... cand. tech. sciences. - Makhachkala, 2012 - 188 p.

9. Slyudikov L.D. Increasing the resource of car tires: Author's abstract. dis ... doct. tech. sciences. - M. 1993 .- 43 p.

10. GOST 28169-89. Pneumatic tires. Methods for determining the wear resistance of tires during road tests. M. Publishing house of standards. 1989, 13 p.

11. O'z RH 52.006: 2009 "Standards of operational mileage of automobile tires" Guidance document. UzGosstandart, 2009 .- 18 $p$.

12. https: //statpsy.ru/pearson/formulapirsona/

13. www.chem21.info/

\section{Corresponding author}

Umidbek Yusupov can be contacted at: umidyusupov20161978@gmail.com 

